\title{
EINVENTING THE BALTIC SEA
REGION: FROM THE HANSA TO THE
EU-STRATEGY OF 2009
}

\section{Michael North}

University of Greifswald, E-Mail: north@uni-greifswald.de

\section{Acknowledgments}

This paper has been presented at the Third International Conference on Nordic and Baltic Studies in Romania: European Networks: the Balkans, Scandinavia and the Baltic World in a Time of Crisis hosted by the Romanian Association for Baltic and Nordic Studies and Valahia University of Târgoviste, and sponsored by the Romanian National Research Council, May 25-27, 2012.

\begin{abstract}
:
The political changes of 1989 stimulated a new perception and perspective of the Baltic Sea Region. And this gained momentum with the Eastern Enlargement of the EU. The new situation encouraged research as well. In this context the "Baltic Sea" is not an unchangeable physical setting, but also a construction of different actors or protagonists. People and powers continuously reinvent the Baltic Sea Region. That is why; the following paper focuses on the different notions of the Baltic Sea Region from the Middle Ages up to now and also examines the recent EU-Strategy of this region.

\section{Rezumat:}

Schimbările politice din 1989 au stimulat o nouă percepție şi perspectivă asupra regiunii Baltice. Aceasta a luat amploare odată cu extinderea Uniunii Europene spre est. Noua situație a încurajat şi cercetarea. In acest context, "Marea Baltică nu este un decor fizic invariabil, ci o construcție a diferiți actori şi protagonişti. Persoane şi puteri reinventează continuu regiunea Mării Baltice. Iată de ce, acest text se concentrează pe diferite noțiuni ale regiunii Mării Baltice din Evul Mediu până în prezent şi examinează, de asemenea, recenta strategie a Uniunii Europene din această zonă.
\end{abstract}

Keywords: Baltic Sea Region; Hansa; Adam of Bremen; EU-Strategy; spatial turn; dominium maris Baltici; model region 


\section{Introduction}

From prehistoric times the Baltic region witnesses a closely connected settlement of different ethnic and linguistic communities, for example of Germanic, Slavonic, Baltic or Finno-Ugric origin. These communities/societies developed during the Middle Ages and the Modern Era into nations and states. In several cases (Finland and the Baltic Countries) state building took place only in the $20^{\text {th }}$ century. Moreover, due to the changing domination exerted by different powers over the Baltic Sea, the political pertinence of the coastal areas shifted many times. For many people, therefore, the history of the Baltic seems to be a history of warfare and struggle for dominion: between Poland and the Teutonic Order, between Denmark, Sweden and Poland; between Russia and Sweden etc. Those struggles and tensions coined enduring stereotypes. These stereotypes were - or still are - so effective in blocking the view on the Baltic Region as an area of intense cultural exchange. Here burgening communication by shipping, migration and integration of foreignness stimulated a process of cultural transformation that counteracted political development. Thus emerged supra-national cultures in the Baltic Region; the Viking culture, the culture of the Hanse, Netherlandisation, Sovietization etc. ${ }^{1}$

Crucial were the political changes of 1989 that stimulated a new perception and perspective of the region. And this gained momentum with the Eastern Enlargement of the EU. The new situation stimulated research as well. ${ }^{2}$ Although historians from the countries of the Baltic Sea Region have been writing on the Baltic from their different perspectives, a synthesis like Fernand Braudel's concept of the Mediterranean is demanded from time to time. ${ }^{3}$ However, I wish to contend, that we would

\footnotetext{
1 Karl Schlögel, Im Raume lesen wir die Zeit: über Zivilisationsgeschichte und Geopolitik (München/Wien: Hanser 2003), 68f.

2 David Kirby, Northern Europe in the Early Modern Period: The Baltic World 1492-1772 (London: Longman 1990); David Kirby, The Baltic World 1772-1993: Europe's Northern Periphery in an Age of Change (London: Longman 1995); Matti Klinge, Die Ostseewelt (Helsinki: Otava 1995); Alan Warwick Palmer, Northern Shores: A History of the Baltic Sea and its Peoples (London: Murray 2005).

${ }^{3}$ Fernand Braudel, La mediterranee et le monde mediterraneen a l'epoque de Philippe II (Paris: Colin 1949); German translation: Fernard Braudel, Das Mittelmeer und die mediterrane Welt in der Epoche Philipps II., 3 Vols. (Frankfurt/Main: Suhrkamp 1990). Critical David Abulafia, 'Mediterraneans'. In: Rethinking the Mediterranean, ed. William V. Harris (Oxford 2005), 6494, here 65. See also Abulafia's The Great Sea: A Human History of the Mediterranean (London: 6
} 
no longer need a synthesis along Braudel's model that is dominated by the physical setting (in which its inhabitants were forced to make a living). In the meantime concepts of space and regions have changed (spatial turn). Spaces and regions are understood as constructions, constructs of different actors or protagonists.

So there is not only an unchangeable physical setting "Baltic Sea" that determines the region, but also people or powers interacting; people that continuously reinvent the Baltic Sea Region. That is why, in my contribution, I shall first focus on the different notions of the Baltic Sea Region from the Middle Ages up to now and then examine the recent EUStrategy for the Region.

\section{Medieval and Modern Notions of the Baltic Sea}

The first notion on the Baltic Sea Region was created in the $11^{\text {th }}$ century by Adam of Bremen in his chronicle on the History of the Church of Hamburg (Gesta Hammaburgensis Ecclesiae Pontificum). Here he spoke about the successful mission of the archbishopric of Hamburg-Bremen in the North, thus designating the Baltic Sea Region as a religious and missionary zone. He described the travel of archbishop Unni in the track of St. Ansgar across the Baltic Sea to Birka in Sweden with the words "mare balticum remigans" ("traveling over the Baltic Sea"). In the fourth book of his history Adam of Bremen for the first time characterized the nature of the Baltic as follows: "Nunc autem, [...], aliquid de natura Baltici maris dicere [...] Sinus ille ab incolis appellantur 'Balticus' eo quod in modo baltei longo tractu per Sciticas regiones tendatur [...] ["Now, to say something about the nature of the Baltic Sea [...] this gulf is called Baltic by the inhabitants because it stretches like a belt to the regions of the Scythians"]. ${ }^{4}$ Apart from this letter,

Oxford University Press 2012). For a natural-geographical focus on the Baltic Sea see
Hansjörg Küster, Die Ostsee: Eine Natur- und Kulturgeschichte (Munich: Beck Verlag 2002). For
an economic and cultural history see Michael North, Geschichte der Ostsee. Handel und
Kulturen (Munich: Beck Verlag 2011).
4 «Sinus ille ab incolis appelatur Balticus, eo quod in modum baltei longu tractu per
Scithicas regiones tendatur usque ad Grecium idemque mare Barbarum seu Pelagus
Sciticum vocatur a gentibus, quas alluit, barbaris.» Magistri Adam Bremensis Gesta
Hammaburgensis Ecclesiae Pontifi cum, ed. B. Schmeidler (Hannover/Leipzig ${ }^{31917), ~ 58,}$
237f.
«Sinus quidam ab occidentali oceano orientem versus porrigitur, longitudinis quidem
incopertae, latitudinis vero quae usquam centum milia passuum excedat, cum in multis
locis contractior inveniatur. Hunc multae circumsedent nationes, Dani siquidem ac Suenos, 
Adam mentioned the Normans, the Slavs, the Estonians and other peoples living along the shores of the Baltic Sea. ${ }^{5}$

\section{Fig. 1: Northern Europe and the Baltic Sea Region according to Adam of Bremen ${ }^{6}$}

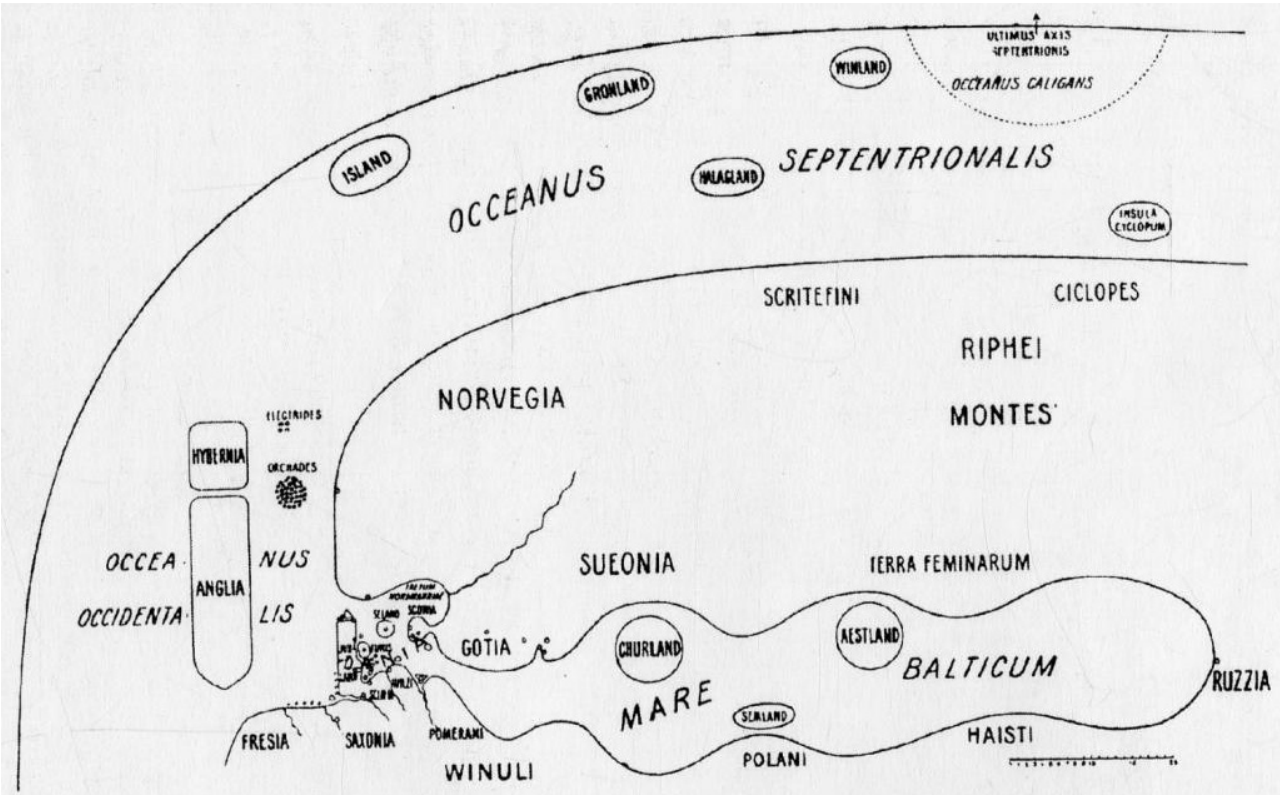

Karte I. Der Norden nach der Auffassung Adams von Bremen.

Rekonstruktion von A. Bjørnbo (Aarbøger 1909, s. 150). Eine Seetagereise ist $=3 \frac{1}{2}$ Landtagereisen berechnet.

In the $13^{\text {th }}$ century the Baltic Sea becomes visible as a region of pilgrims and trade. Duke Albert of Saxony granted 1241 safe conduct to merchants travelling from the East Sea to the West Sea ("de orientali mari ad occidentae mare"). ${ }^{7}$ The Papal nuntio Guido exempted 1266 the pilgrims on their way "De orientali mari ad occidentae mare [que] Osterse et westerse vulgariter nuncupantur" from the strand law, the wrecking by coastal communities in the case of an ship accident.

quos Nordmannos vocamus, et septentrionale litus et omnes in eo insulas tenent. At litus australe Sclavi et Aisti et aliae diversae icolunt nationes.» Einhardi Vita Karoli Magni, O. Holder-Egger, ed, Hannover 1911, Ndr. 1965, Kap. 12, S. 15.

5 Josef Svennung, Belt und Baltisch, Ostseeische Namenstudien. Mit besonderer Rücksicht auf Adam von Bremen (Uppsala/Wiesbaden: Lundequist 1953), 24-50.

6 Published in: Josef Svennung, Belt und Baltisch, Ostseeische Namenstudien. Mit besonderer Rücksicht auf Adam von Bremen (Uppsala/Wiesbaden: Lundequist 1953), 27.

7 Codex Diplomaticus Lubecensis (UBStL) 1 (Nachdruck Lübeck 1976), 92-93, 267. 
Especially with the expansion of Hanseatic trade in the Baltic Sea and in the North Sea the cities corresponded. For example, in 1294 the city of Zwolle on the river Ijssel wrote to the city of Lübeck about "mare orientale" (Eastern Sea) and the "mare occidentale" (Western Sea). ${ }^{8}$

A century later, in 1401 Albrecht of Bavaria, Duke of Holland, Zeeland and Hainaut promised safe conduct for the deputies of the Hanseatic cities, which he describe as "ghemeenre steden bi der osterzee" (common cities of the East Sea). ${ }^{9}$

In the $15^{\text {th }}$ and $16^{\text {th }}$-century Netherlands the terms "Oostersche zee and Oostzee or mer d'oost and mer d'Oostlande" were increasingly used, whilst humanist writers still spoke about "Mare Balticum". The Swedish chronicler Olaus Magnus mentioned in his "Historia de gentibus septentrionalibus" "mare Balticum", "mare Gothicum, seu Finnonicum ac Livonicum" or "mare Sveticum, mare Bothnicum" and "mare Germanicum". When he referred to mare Balticum, he meant in this context the southern coast and waters of the Baltic Sea. ${ }^{10}$

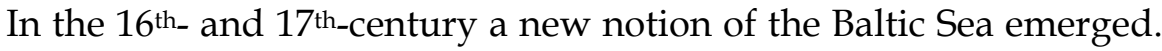
Especially battles for military and economic interests led to the notion of "dominium maris Baltici" (dominion over the Baltic Sea). Since Denmark attempted to monopolize the access to the Baltic Sea via the Danish Sound, other seafaring neighbours in the Baltic Sea such as Sweden and Poland, opposed the claim militarily and medially. The Dutch Republic, however, tried to secure the free passage to the Baltic Sea and their trading interests. In this context, matters of the Baltic Sea (saken van de Oostzee) became prominent in the correspondence of Dutch politicians' - such as Johan de Witt, Coenraad von Beuningen and Anthonie Heinsius. In the early $18^{\text {th }}$

\footnotetext{
${ }^{8}$ Hansisches Urkundenbuch 1, 399.

${ }_{9}^{9}$ Geleitbrief des Herzogs Albrecht von Bayern für die Hansestadte, 10. April 1401, Huibert Antoine Poelman, ed, Bronnen tot de geschiedenis van den Oostzeehandel, eerste deel 1122-1499, eerste stuk, Grote Serie 35 ('s-Gravenhage: Nijhoff 1917), 182. I am indepted to Hielke van Nieuwenhuize for his overview on the Dutch sources.

10 Jörg Hackmann, „Was bedeutet „,baltisch“? Zum semantischen Wandel des Begriffs im 19. und 20. Jahrhundert, Ein Beitrag zur Erforschung von mental maps". In: Buch und Bildung im Baltikum (Festschrift für Paul Kaegbein zum 80. Geburtstag), ed. Heinrich Bosse, O. H. Elias, Rorbert Schweitzer (Münster: Lit-Verlag 2005), 15-39, here 21. The various notions are Oostersche Zee, Ostersche Zee, Oestersche Zee, Oistersche Zee. Rudolf Häpke, ed, Niederländische Akten und Urkunden zur Geschichte der Hanse und zur deutschen Seegeschichte, I, 1531-1557 (Munich/Leipzig: Duncker \& Humblot 1913), 105f, see also Der Hof von Holland an Statthalter Hoogstraten, 18. Juni 1533, 116-119.
} 
century a special committee "Directie van de Osstersche Handel en Rijderijen" was established for this trading and shipping area, while the Russian trade was supervised by the "Directie van den Moscovische handel".

At the same time the academic and scientific interest in the Baltic Sea rose. Zedler's Encyclopedic Dictionary includes an article on the Baltic Sea, and a little bit later the Berlin linguist Georg Heinrich Ferdinand Nesselmann coined the term 'Baltic languages' for the Lithuanian, Curonian, Old Prussian and Latvian. This interest coincided with a shift of the political pertinence of the Baltic provinces from Sweden to Russia due to the Peace of Nystad (1721). At the beginning Russia named its new provinces "ostzejskij", designating them as Baltic Sea Provinces. In the later 19th century the official name became "pribaltijskij", which means located at the Baltic Sea. This meant a change in perception, since the provinces where now perceived as the coastal provinces of the Russian Empire. "Baltic" (Baltisch) became at the same time a label for the Baltic Germans.

\section{Emergence, Occupation and Re-Emergence of the Baltic}

\section{States}

After the Foundation of the new Baltic States in 1918/19 the Western powers took "Baltic" as a term to design the new Baltic States. This period saw several attempts to create a "Baltic" or "Baltic Sea" identity. Although a 'Baltic League' to coordinate the foreign policy from Sweden to Poland failed, a number of initiatives proved effective. Among those were the foundation of the Baltic Institute in Torun (1925) and the Journal "Baltic Countries: A survey of the peoples and states of the Baltic with special regard to their history, geography and economics" (1935f.)11. In 1937 historians from the Baltic Sea countries met for the Conventus primus historicum Balticorum. ${ }^{12}$

The Soviet occupation of the Baltic States and their integration into the Soviet Union as well as the loss of the German territories along the Baltic coast reduced the interest in the Baltic Sea Region which was only kept alive by emigrants. Only in the 1970s and especially in the 1980s the process of détente built new bridges. Due to the reestablished ferry connection between Helsinki and Tallinn by the end of the 1970s, 90,000 people yearly visited Tallinn - although the visitors consisted to a large

\footnotetext{
11 Title change to Baltic and Scandinavian countries (1937).

12 Marta Grzechnik, Regional Histories and Historical Regions. The concept of the Baltic Sea Region in Polish and Swedish Historiographies (Frankfurt am Main: Peter Lang 2012). 
extent of Finnish Vodka-Tourists -, yet Estonians and Finns began to familiarize themselves with each other again. Furthermore, scientific exchange in the area slightly increased. In this context the debate on a "New Hansa", stimulated by the Schleswig-Holstein Prime Minister Björn Engholm gained momentum. Engholm wanted to re-establish Baltic Sea relationships with reference to the old German Hansa. He created cultural initiatives, such as "Ars Baltica" and "Jazz Baltica". However Engholm's program became obsolete due to the fundamental changes of 1989 and the subsequent dissolution of the Soviet Union. The perception of the region changed once more. Cities and countries which had been perceived as strange and far away were suddenly discovered in the neighborhood.

Facing the political changes, politicians designed a new perspective for the Baltic Region. Scandinavia especially, where only Denmark belonged to the EU, was expecting to be marginalized in the dynamics of European unification. That is why, in 1992, at the initiative of the Danish and German Foreign Ministers Uffe Ellemann-Jensen and Hans-Dietrich Genscher, the countries of the Baltic Sea Region founded Council of the Baltic Sea States (CBSS). ${ }^{13}$ Since the CBSS included Iceland and Norway, the Baltic Sea Region was politically redefined. At the same time Finland, Sweden and Norway applied for EU-membership, but only Swedes and Fins opted for it, while the Norwegians declined. Apart of EU-integration Finland wanted to preserve its traditional middle man role between East and West and developed a strategy of "Northern Dimension". Under this umbrella Finland took the lead in the dialog with Post-Sovietic Russia. After Sweden's and Finland's entry into the EU Estonia, Latvia and Lithuania applied together with Poland, the Czech Republic, Slovakia, Hungary and Slovenia for EU-membership. The negotiations took quite some time, since the EU wanted to solve the problems of citizen rights for the Russian speaking population. On May 2004 the Baltic States together with Poland, the Czech Republic, Slovakia, Hungary, Slovenia, Cyprus and Malta became members of the EU. A further step of integration was the ratification of the Schengen Agreement in December 2007. Thus the interior

13 Marko Lehti, „Possessing a Baltic Europe: Retold National Narratives in the European North". In: Marko Lehti and D. J. Smith (eds.), Northern and Baltic Experiences of Post-Cold War Identity Policies (London 2003), 11-49; Marko Lehti, „Paradigmen ostseeregionaler Geschichte: von Nationalgeschichte zur multinationalen Historiographie“. In: Jörg Hackmann and Robert Schweitzer (eds.), Nordosteuropa als Geschichtsregion (Lübeck: Schmidt-Römhild Verlag, 2006), 494-510. 
border controls disappeared within the EU and the Baltic Sea Region (apart from Kaliningrad). A new border regime, however, was established at the EU-outer-border, whereby the new members gained a special role of border surveillance towards Russia, Belarus and Ukraine. ${ }^{14}$

\section{The Baltic Sea as a model region}

During the first decade of the 21st century the euphoria which had arisen with the various cooperation in the Baltic Sea Region and the EUintegration was replaced by dissolution and stagnation. Having been accepted by the EU, the new member-states had to compete in Brussels for funding. Brussel's bureaucrats decided over future regional activities and competing projects. In this respect cooperation between neighbouring states in the Baltic Sea Region became attractive again. In this context a delegation, consisting of seven members of the European Parliament from Finland, Estonia, Latvia, Germany and Great Britain addressed a memorandum to the President of the EU-commission, demanding an improved cooperation between EU-institutions and the regional Baltic Sea organizations. In the following years politicians from the region suggested new forms of cooperation and put the Baltic Sea area again on the European agenda. One example was the speech of the Lithuanian foreign minister Artis Pabriks during the Lithuanian presidency of the Baltic Sea Council.

“We don't look alike, we don't speak one language, we don't live in one country and we don't have a joint team in world ice hockey championship. But we share the Baltic Sea, a common history, values and spirit of dynamism, skillfulness and creativity. However, what is important - we share the same dreams about our region's future: to be competitive, stable, advanced and always a developing region." 15

One year later during the Latvian presidency of the Baltic Sea Council the Latvian foreign minister launched the project "Balticness" representing the Baltic Sea as artery of the Baltic region and creating Baltic identity via Jazz concerts and photo exhibitions.

\footnotetext{
14 Burkhard Auffermann, „Finnland: Neuorientierung nach dem Kalten Krieg“. In: Politik und Zeitgeschichte 43 (1992): 36-47.

${ }^{15}$ Cited after Marko Lehti, Baltic Region in Becoming: From the Council of the Baltic Sea States to the EU's Strategy for the Baltic Sea Area (2009), http://www.lfpr.lt/uploads/File/200922/Marko\%20Lehti.pdf, 9f.

12
} 
A new impact for Baltic Sea policy came with the Swedish government, especially the Swedish European minister Cecilia Malmström who gave regional policy in the Baltic priority. She declared the Baltic Sea Region to become the strongest European region of economic growth and invited in 2008 "stakeholders" for the future region to a conference in Stockholm. At the conference the eight EU-states of Baltic Sea Region, the non-EU members Russia, Belarus and Norway, 31 regional institutions, 48 intergovernmental and non-governmental organizations as well as private individuals (entrepreneurs and academics) took part. ${ }^{16}$ In a bottom-upprocess suggestions for the future development of the Baltic Sea Region were put forward that entered into the formulation of the Baltic Sea Strategy. This aims to make the Baltic Sea Region a Model Region for European Integration with the following characteristics:

1. An environmental sustainable region

2. A prosperous region

3. An accessible and attractive region

4. A safe and secure region ${ }^{17}$

This strategy was agreed during the Swedish presidency of the European Council in October 2009. The implementation of the strategy will take place in a number of flagship projects which have either strategic relevance for the whole region or specific importance for individual regions. One project - the replacement of phosphates in detergents - aims to limit the nitrate influx into the Baltic Sea, while the Baltic Energy Market Interconnection Plan (BEMIP) seeks to balance bilateral energy agreements (such as North Stream).

Some of the projects are on the way. Furthermore, cooperation has been celebrated during many conferences in 2012 in the context of the 20th anniversary of the Baltic Sea Council. The success of the Baltic Sea Council

\footnotetext{
16 Good overview over governmental and nongovernmental organisation offer Michael Karlsson, Transnational Relations in the Baltic Sea Region (Huddinge: Södertörns högskola 2004); R. Bördlein, „Regionale und transnationale Zusammenarbeit von staatlichen und nichtstaatlichen Organisationen“. In: Der Bürger im Staat 54 (2004), H. 2/3, 147-153; Carmen Gebhard, Unraveling the Baltic Sea Conundrum: Regionalism and European Integration Revisited (Baden-Baden: Nomos 2009).

17 For the EU-strategy see Lehti, Baltic Region (2009); Pertti Joenniemi, „The EU Strategy for the Baltic Sea Region. A Catalyst for What?" In: DIIS Brief (2009): 1-6 (www.diis.dk/graphics/Publications/Briefs2009/pjo_eu_strategy_balticsearegion.pdf); Carsten Schymik and Peer Krumrey, EU Strategy for the Baltic Sea Region. Core Europe in the Northern Periphery? (Working Paper FG 1, 2009/08, April 2009, SWP Berlin): 1-21.
} 
and institutional cooperation, however, will limit the attention been paid to the Baltic Sea Strategy by EU-institutions especially the Commission. Besides, it is not yet clear whether the Commission or the EU memberstates in the Baltic Sea Region are taking the lead in implementing strategy and flagship projects. The interaction with non-EU partners, such as Russia, Belarus and the Ukraine will be crucial for the further development. There are still regional impediments which hamper, for example EU-Russia cooperation. ${ }^{18}$ These should, however, be overcome during the current Russian presidency of the Baltic Sea council.

\section{Conclusion}

This essay shows that the Baltic Sea Region underwent significant constructions by various protagonists from the period of Adam of Bremen in the $11^{\text {th }}$ and the Hansa in the $13^{\text {th }}$ century up to the EU-Strategy of 2009. Whereas Adam of Bremen constructed the Baltic as a missionary region, the Hansa constituted the Baltic Sea as a trading area. Although, the Baltic Sea Area remains to be a trading area until now, from the $16^{\text {th }}$ century in the eyes of rulers and politicians, the Baltic Sea Area became an area of warfare and struggle for dominium. Whilst the $19^{\text {th }}$ century acknowledged cultural exchange and the early $20^{\text {th }}$ century political cooperation as element of the region, the Sovietic dominated "Sea of Peace" was only redesigned as a "New Hanseatic Area" in the 1980s. After 1989 freedom followed peace. EU membership and finally the EU-Strategy of 2009 gave the area a new design as a model region of regional integration.

These different notions of the Baltic Sea and Baltic Sea Region elucidate the constructiveness of a region, which is often ignored by politicians and even by contemporary historians.

It is therefore most important to communicate the history and as well the present EU-strategy into the minds of the people living on the Baltic coasts. Only via this process, can the reinvention of the Baltic Sea Region as a Model Region for European Integration be accepted across the

\footnotetext{
18 Rikard Bengtsson, „The EU Strategy for the Baltic Sea Region: Golden or missed opportunity“. In: Andreas Kasekamp, ed, Estonian Foreign Policy. Yearbook 2011 (Tallinn: Kirjastus Varrak 2012), 7-31. 
region. This could stimulate regional cooperation in other regions such as the Mediterranean, the Black Sea area or even the South China Sea. ${ }^{19}$

\section{References:}

\section{A. Books, articles, published documents:}

Abulafia, David, 'Mediterraneans'. In: Rethinking the Mediterranean. Ed. William V. Harris. Oxford 2005.

Abulafia, David. The Great Sea: A Human History of the Mediterranean. London: Oxford University Press, 2012.

Auffermann, Burkhard. „Finnland: Neuorientierung nach dem Kalten Krieg“. In: Politik und Zeitgeschichte 43 (1992): 36-47.

Bengtsson, Rikard. „The EU Strategy for the Baltic Sea Region: Golden or missed opportunity“. In: Estonian Foreign Policy. Yearbook 2011. Ed. Andreas Kasekamp. Tallinn: Kirjastus Varrak 2012, 7-31.

Bördlein, R. „Regionale und transnationale Zusammenarbeit von staatlichen und nichtstaatlichen Organisationen“. In: Der Bürger im Staat 54 (2004), H. 2/3, 147-153.

Braudel, Fernand, La mediterranee et le monde mediterraneen a l'epoque de Philippe II. Paris: Colin 1949; German translation: Fernard Braudel, Das Mittelmeer und die mediterrane Welt in der Epoche Philipps II., 3 Vols. Frankfurt/Main: Suhrkamp 1990.

Codex Diplomaticus Lubecensis (UBStL) 1. Nachdruck Lübeck, 1976, 92-93, 267.

Einhardi Vita Karoli Magni, O. Holder-Egger, Ed,. Hannover, 1911, Ndr. 1965, Kap. 12, S. 15.

Gebhard, Carmen. Unraveling the Baltic Sea Conundrum: Regionalism and European Integration Revisited. Baden-Baden: Nomos 2009.

Grzechnik, Marta, Regional Histories and Historical Regions. The concept of the Baltic Sea Region in Polish and Swedish Historiographies. Frankfurt am Main: Peter Lang 2012.

Hackmann, Jörg, „Was bedeutet „baltisch“? Zum semantischen Wandel des Begriffs im 19. und 20. Jahrhundert, Ein Beitrag zur Erforschung von mental maps". In: Buch und Bildung im Baltikum (Festschrift für

\footnotetext{
19 Michael North and Barnard Turner, "The Baltic Sea and South China Sea Regions: Incomparable Models of Regional Integration?“. In: Asia Europe Journal 8 (2010): 271-277.
} 
Paul Kaegbein zum 80. Geburtstag). Ed. Heinrich Bosse, O. H. Elias, Rorbert Schweitzer. Münster: Lit-Verlag 2005.

Häpke, Rudolf, ed. Niederländische Akten und Urkunden zur Geschichte der Hanse und zur deutschen Seegeschichte, I, 1531-1557. Munich/Leipzig: Duncker \& Humblot 1913.

Karlsson, Michael. Transnational Relations in the Baltic Sea Region. Huddinge: Södertörns högskola 2004.

Kirby, David. Northern Europe in the Early Modern Period: The Baltic World 1492-1772. London: Longman 1990.

Kirby, David. The Baltic World 1772-1993: Europe's Northern Periphery in an Age of Change. London: Longman 1995.

Klinge, Matti. Die Ostseewelt. Helsinki: Otava 1995.

Küster, Hansjörg. Die Ostsee: Eine Natur- und Kulturgeschichte. Munich: Beck Verlag 2002.

Lehti, Marko. „Paradigmen ostseeregionaler Geschichte: von Nationalgeschichte zur multinationalen Historiographie“. In: Jörg Hackmann and Robert Schweitzer eds. Nordosteuropa als Geschichtsregion. Lübeck: Schmidt-Römhild Verlag, 2006. 494-510.

Lehti, Marko. „Possessing a Baltic Europe: Retold National Narratives in the European North“. In: Marko Lehti and D. J. Smith. Eds. Northern and Baltic Experiences of Post-Cold War Identity Policies. London 2003.

Magistri Adam Bremensis Gesta Hammaburgensis Ecclesiae Pontifi cum. Ed. B. Schmeidler. Hannover/Leipzig 31917.

North, Michael and Barnard Turner. „The Baltic Sea and South China Sea Regions: Incomparable Models of Regional Integration?". Asia Europe Journal 8 (2010): 271-277.

North, Michael. Geschichte der Ostsee. Handel und Kulturen. Munich: Beck Verlag 2011.

Palmer, Alan Warwick. Northern Shores: A History of the Baltic Sea and its Peoples. London: Murray 2005.

Poelman, Huibert Antoine, ed. Bronnen tot de geschiedenis van den Oostzeehandel, eerste deel 1122-1499, eerste stuk, Grote Serie 35. Gravenhage: Nijhoff 1917.

Schlögel, Karl, Im Raume lesen wir die Zeit: über Zivilisationsgeschichte und Geopolitik. München/Wien: Hanser 2003, 68f.

Schymik, Carsten and Peer Krumrey. EU Strategy for the Baltic Sea Region. Core Europe in the Northern Periphery? Working Paper FG 1, 2009/08, April 2009, SWP Berlin: 1-21.

Svennung, Josef, Belt und Baltisch, Ostseeische Namenstudien. Mit besonderer Rücksicht auf Adam von Bremen. Uppsala/Wiesbaden: Lundequist 1953, 24-50. 


\section{B. Web postings:}

Lehti, Marko. Baltic Region in Becoming: From the Council of the Baltic Sea States to the EU's Strategy for the Baltic Sea Area (2009). http:/ / www.lfpr.lt/uploads/File/2009-22/Marko\%20Lehti.pdf, 9f.

Lehti, Marko. Baltic Region (2009); Pertti Joenniemi, „The EU Strategy for the Baltic Sea Region. A Catalyst for What?“ In: DIIS Brief (2009): 16 , www.diis.dk/graphics/Publications/Briefs2009/pjo_eu_strategy_b alticsearegion.pdf. 